\title{
Analysis on the Influence and Application of Financial Management Model on Financial Management
}

\author{
Jin Wenjuan, a , Gong Hong ${ }^{2, ~ b}$, Feng Ying ${ }^{3, c}$ \\ ${ }^{1}$ The College of Economics and Business Administration, School of Xi'an University of Posts \& \\ Telecommunications University, Xi'an 710000, China \\ ${ }^{2}$ Graduate School of Xi'an University of Posts \& Telecommunications University, School of Xi'an \\ University of Posts \& Telecommunications University, Xi'an 710000, China \\ ${ }^{3}$ The College of Economics and Business Administration, School of Xi'an University of Posts \& \\ Telecommunications University, Xi'an 710000, China \\ a1054655099@qq.com, ${ }^{\text {bgonghong@xupt.edu.cn, }{ }^{c} 1528279839 @ q q . c o m}$
}

Keywords: financial sharing center; financial management; fund management

\begin{abstract}
With the development of economic globalization and Internet technology, large enterprises have set up branches all over the world. Major enterprises pay very high cost in management, and corporate financial costs continue to rise. Therefore, the importance of financial management is self-evident. As an important part of the connotation of enterprise management, the company has been pursuing a method to optimize the financial management model for many years. Through exploring the business activities of the company for many years, the financial sharing service mode appeared in the 1990s. This is an innovative financial management model that "fine management creates benefits" with simple operation, large quantity, strong repeatability and so on. The financial accounting business of each branch is concentrated in the finance department. Sharing services, realizing the standardization of business process, and the process of process reengineering enable enterprises to separate financial accounting and management. Accounting is more in line with the accuracy of the enterprise, to optimize the management idea, optimize the financial management mode of large enterprises, optimize the management mode, and reduce the manufacturing cost.
\end{abstract}

\section{The meaning of Financial sharing Model}

Financial sharing Service Model A method of redistributing the financial personnel of each unit in a group enterprise by establishing a financial sharing center can realize the optimization and cooperation strategy of the enterprise. The purpose of the financial sharing service model is to share the information resources within the enterprise to reduce the cost rise and the decline of production efficiency caused by the communication between different business within the enterprise. In addition, through the implementation of shared financial management mode, enterprises can not only improve the speed of processing information, but also enable the functional departments to give full play to their original professional knowledge and skills. 


\section{The comparison of Financial Management Mode and the Research significance of shared Financial Management Mode}

The financial management of enterprises can be divided into three parts: traditional financial management, financial outsourcing services and financial sharing services.

\subsection{Traditional financial management}

No matter how many subsidiaries or branches of a group company, no matter how much or complex business content, the traditional financial management model can be divided into three parts: internal needs, external needs and settlement needs. Therefore, although the traditional accountants are doing repetitive and monotonous work, the number of traditional financial personnel is still increasing with the expansion of the scale of the enterprise.

\subsection{Financial outsourcing services}

Financial service outsourcing is a kind of financial strategic management mode. Enterprises outsource some items or procedures in the process of financial management to external professional organizations. According to its outsourcing form, traditional financial outsourcing is divided into modern financial outsourcing and network financial outsourcing.

Traditional financial outsourcing mainly divides financial management activities into several modules according to the needs of enterprises, such as general ledger accounting, current accounting and so on. Comparative advantage is the leading level of professional organization in the industry. If financial management is outsourced to banks and other financial institutions, declining accounts receivable and accounts receivable will be outsourced to management.

The modern financial outsourcing network is an Internet financial platform that provides financial services to applications (such as ASP, application service providers) through the form of contracts. Or the agreement that the financial system of the enterprise, in whole or in part, goes to the outsourcing service provider, which uses the Internet concession site instead of generating functionality, to implement financial process and financial information analysis in the enterprise. The decision-making function is performed by the senior financial managers of the unit, while providing services to ensure the quality of financial information for financial outsourcing and to provide the necessary advice and guidance. The modern network finance outsourcing is the popularization of the network technology to the telecommunication, the traditional finance advanced outsourcing form In 2003, the network platform organically linked the financial function logic to form outsourcing. In recent years, the financial management function, especially the enterprise decision support function, is becoming more and more important in the management. Therefore, the financial business process more and more refined, greatly enriched the content of financial outsourcing.

\subsection{Financial sharing service}

Financial sharing service is based on information technology, based on financial business process processing, optimize organizational structure, standardize process, improve process efficiency, reduce operating costs or create value.

First, reduce operating costs. This allows quantitative calculations and comparisons, such as an analysis of the average number of credentials processed by the shared Service Center each month. The benefits are mainly achieved by reducing the number of personnel and middle-level management. If "shared service centres" were established in a new location, the cost reduction 
would be more pronounced, as local wages would be lower in the new locations normally chosen; By establishing a new organizational structure and rational incentive mechanism in the "shared service center", the employee's work efficiency can be significantly improved and a culture of continuous enterprising can be formed.

Second, improve the level and efficiency of financial management. For example, use the same standard operating procedures for all subsidiaries and eliminate redundant steps and processes; share financial services centres with all financial data and data summaries for relevant subsidiaries; Standardization and updating of IT systems (hardware and software) becomes faster, easier to use and cheaper.

Third, enterprise integration ability and core competitiveness. Companies set up subsidiaries or acquire other companies in new territories, and share service centers serve these new employees. At the same time, company managers are more focused on the company's core business, while other assistive functions are implemented through shared services.

\section{Advantages of Information system in Financial sharing Mode}

\subsection{Specialized division of labor}

The core of traditional accounting organization is the establishment of departments and positions. This easily leads to the organization running inefficient results. This model objectively makes the scope of accounting function too narrow, ignoring the overall strategic objectives. Enterprises should establish accounting positions and financial sharing centers according to the type of business and individual accounting business. The service provided by specialized personnel greatly improves the proficiency and working efficiency of personnel.

\subsection{Form economies of scale}

The financial sharing center can not only concentrate on the accounting work of subsidiary companies, reduce the number of accountants, reduce the operating cost, but also collect data from enterprises, transmit and process it through the network. The efficiency of data processing is further integrated.

\subsection{Business process reengineering}

The financial sharing service center insists on the construction of a complete set of financial control system oriented by process, which can penetrate into the business units of the company, including EVE enterprise procurement, production, marketing, research and development, risk control and so on. Collect information dynamically and timely, adjust and control information.

\subsection{Flat tissue structure}

As a kind of market-oriented enterprise group organization, the agility and agility of technological conditions are related to the competitiveness of enterprises in the complex and changeable environment. Sharing center sharing information, services and resources reduces the organizational defects of management departments, speeds up the transmission of information, and improves the efficiency of information processing. 


\section{The present situation and existing problems of Financial Management of Enterprise groups in China}

(1) The comprehensive fund management system is not perfect, which seriously restricts the financial department's ability to control and control the funds.

Because the fund management level of each subsidiary is different, and the equity relationship within the group is complex, the enterprise group has not yet established a comprehensive fund and management system, which leads to the low efficiency of the capital market within the whole group. A serious obstacle to the Group's control of the Finance Department. Each member company of the group has many customers, the group company can not grasp the capital flow of each subsidiary in time, can not check and supervise the actual financial situation, the scale of operation and the cash flow of each subsidiary. The allocation of capital resources within the group is unreasonable, with some subsidiaries idle and large amounts of capital wasted, while others lack financing.

(2) Cash receipts and payments are managed by internal staff and the headquarters lacks effective monitoring.

Capital can not be evenly distributed in the group, so that the effect of scale effect is good, the synergy of fund management can not be realized, and the financing cost is high. The financing pressure is great, the main body of financing channel is complex, the examination and approval procedure is complicated, the financing scale is limited, and the financing cost is high. Integrated budget management is a management budget preparation, execution, analysis and evaluation of the expectation and control of future activities such as investment, financing, operation and financing.

(3) Group M \& A is faced with great financial pressure, usually group to the bank loans, issuing corporate bonds as the main way of financing, because of some enterprise groups in China. A sound budget management system has not yet been established. The disconnection between budget management and business information and the lack of budget monitoring lead to budget errors which affect the use of funds and the budget management of funds is only a form.

\section{The way of Financial Management system of Group Company under the Mode of Financial sharing}

Under the mode of financial sharing, the optimization of enterprise group financial management system should be carried out according to the overall development strategy. In the following ways:

(1) Improve financial organization group, implement vertical leadership and unified deployment of service personnel, implement service sharing mode, internal or group organization. To the business process, the data carries on the strict analysis and combs, unifies the business processing process and the accounting process. Separate business processing centers according to transaction processing and business cycle, and clean up each center. Based on the operational efficiency of established posts, each post is classified as a lack of accountability.

(2) Perfect group funds centralized management system of enterprise groups can focus on financial decision-making power in the parent company. Strengthening the dispatch and use of headquarters, effectively controlling and supervising the use of subsidiary funds, optimizing the allocation of internal funds of the group, reducing the idle waste of funds, reducing the dependence on external financial institutions, and reducing the financing costs, Speed up the turnover of funds, improve the profitability of the Fund.

(3) To strengthen budget management, enterprise groups of administrative power should establish fund budget management system and establish comprehensive budget management system. Management concept, the establishment of budget management agencies. Develop budget process, design budget approval authority according to management level and responsibility center, improve budget approval rate. In the implementation of budget management, the budget management can 
achieve the best effect through flexible budget and rolling budget. Establish an effective budget difference analysis system, strengthen the budget post-audit, encourage the staff to make joint efforts, so that the financial management personnel should learn from the advanced experience accumulated by multinational companies, rely on the training platform of the group, and conduct financial management training to the enterprises. . Staff in information technology, budget management, risk value, job skills, and other aspects of financial functions from transaction processing to decision support.

(4) To establish an efficient financial sharing information management system enterprise group, its subsidiaries are distributed in a wide range of characteristics. At the same time, the financial management software should be able to provide multi-level security control. Improve the security and reliability of member financial data. The optimization of management mode and the reengineering of business process strengthen business cooperation realize the network operation of financial information system between parent company and subsidiary company realize centralized management of financial information and share company information resources. Improve the group fund management information level. Reduce overall operating costs.

(5) To strengthen the prevention and control of financial risk enterprises should gradually establish a set of standardized internal control management system and risk early warning system and establish the concept of all staff risk management. Improve the group's internal performance audit, restrain, standardize the member's fund management behavior, avoid the enterprise financial risk and experience risk.

\section{Epilogue}

In short, financial sharing service is an effective means to reduce costs and improve efficiency. In short, shared services are an advanced information technology based on Internet. Through the advanced information technology log, the financial sharing service is integrated into the financial sharing service. By means of Internet and so on, the standardization, flow and standardization of financial accounting are realized, and the timeliness and accuracy of financial accounting are guaranteed. Accounting staff to reduce human resources costs, improve financial efficiency and service quality. Focus on the desired business objectives. This process of process reengineering allows businesses to separate money from management accounting Business accounting. Firstly, the essence of the implementation of financial sharing service is a process of business process reengineering, which aims to reduce financial costs. Improving efficiency is the basic aim of enterprises, so cost-leading strategy should be adopted for such an important process reengineering. Managers support and value it. Active coordination and coordination among various departments is essential. The second is accounting financial management mode based on financial sharing service. In order to deal with financial accounting business safely and quickly, it is a stable and secure information technology platform and a unified financial management system. Construction of financial shared service model, financial organization structure, financial personnel management. The construction of interest system is embodied in the financial sharing service as an operating entity independent of other branches of the enterprise and establishing the mutual relationship.

\section{References}

[1] KeMing. Discussion on the Model of Financial shared Control Service [J] .Friends of Juice, 2008 / 12: Lang.

[2] Lv Dan. Financial sharing [J]. Chief Financial Officer, 2010: 10-36.37.

[3] Department of Accounting, Ministry of Finance. From Standardization to guidance. Interpretation of the Standard of Enterprise Accounting Informatization [J]. Finance and Accounting, 20149-13.

[4] Zhang Ruijun, Chen Hu, Xiguang Guangguang, Chang Yan. Research and practice of financial sharing Service Model [J] .Management case study and Review, 2008 / 03: 19-21. 
[5] Zhang Ruijun, Chen Hu, Zhang Yongji. Research on the key factors of process reengineering for Enterprise Group Financial sharing Service-based on ZTE Group Management practice [J]. Accounting Research, 2010 / 03: 58-59.

[6] Chiu Yan, Wang Zhaolui. Misunderstandings and key points of Financial sharing for the first time [J] .Friends of Accounting, 2010 / 02: 52-53.

[7] Jiang Jianqing. Study on the Management of branches of State-owned Commercial Banks [J] .Financial Research, 2001 / 09: 1-5.

[8] Zhu Feng. Flat Management and organizational reorganization of State-owned Commercial Banks [J] .China Finance, 200110: 2-43.

[9] Huang Ruifeng. Reform and Optimization of the organizational structure of State-owned Commercial Banks [J] .Journal of Wuhan training Institute of Agricultural Bank of China, 2002 / 02: 05-7. 